AperTO - Archivio Istituzionale Open Access dell'Università di Torino

Hunters and Gatherers in East Africa and the Case of Ongota (Southwest Ethiopia)

This is a pre print version of the following article:

Original Citation:

Availability:

This version is available http://hdl.handle.net/2318/1743487

since 2020-07-09T12:46:43Z

Publisher:

Cambridge University Press

Published version:

DOI: $10.1017 / 9781139026208$

Terms of use:

Open Access

Anyone can freely access the full text of works made available as "Open Access". Works made available under a Creative Commons license can be used according to the terms and conditions of said license. Use of all other works requires consent of the right holder (author or publisher) if not exempted from copyright protection by the applicable law. 
Part II

Africa 



\title{
$5 \quad$ Hunters and Gatherers in East Africa and the $Q$ Case of Ongota (Southwest Ethiopia)
}

\author{
Graziano Savà and Mauro Tosco
}

\section{$5.1 \quad$ Introduction}

Quite a sizeable number of marginal communities are found in East Africa, most notably along and in the proximity of the Rift Valley. Almost everywhere, from Ethiopia to Tanzania, one finds specific occupational outcast groups (usually tanners, blacksmiths, experts in traditional medical and magical practices, and so on), as well as hunting and gathering communities, to which fishermen and bee-keepers must be added.

It is at least convenient (even if not always easy, nor maybe theoretically sound) to draw a separating line between the occupational outcast groups and the hunting and gathering communities on the basis of their ethnic and linguistic affiliation: the former are found by and large within a broader ethnic and linguistic community, of which they share typical cultural and sociopolitical traits. On the other hand, hunting and gathering communities may better be considered separate entities; they are (often geographically, but even more culturally) distinct from the neighboring dominating group - to which, of course, they are tightly connected by a complex net of political obligations and economic interests.

Here our interest and our considerations will be strictly limited to the hunting-gathering groups. But even a cursory discussion of all the peoples that fall, one way or another, under this rubric in East Africa seems an impossible task within the limits of a single chapter. Only a few traits that seem common will be discussed:

We wish to gratefully acknowledge the collaboration of Sophia Thubauville (University of Mainz), who accompanied Graziano Savà on a short survey fieldwork in the Ongota village of Muts'e in August 2007 and kindly allowed the authors to include her map of the Ongota history of movements. Graziano Savà's research on Ongota was funded by the Hans Rausing Endangered Languages Documentation Programme. The included data on Ts'amakko come from Savà (2005). This pubblication is the result of a $\mathrm{PhD}$ project financed by the CNWS, University of Leiden. Fieldwork was also supported by the Dutch organization Ro. Graziano Savà is greatly indebted to these institutions for their fundamental support. 
- Language shift toward the language of a dominating group is widespread: there is evidence (as the present chapter will detail with regard to a specific group in southwestern Ethiopia) that language shift can even be cyclic.

- Ethnic assimilation to a neighboring pastoral community is equally common, although it must not be confused with language shift: a group can either shift its language affiliation without assimilating itself (i.e., without losing its distinctiveness), or retain its language but accept a new ethnic identity.

But it is in regard to the very origin of the hunting-gathering groups that two opposite historical hypotheses have been put forward and still dominate the field. To these we turn in the following section.

\subsection{Two Ways of Looking at Hunter-Gatherers}

Broadly speaking, the hunter-gatherers of East Africa have been subject to two radically different models of analysis. The first considers them as "relics" - i.e., as the last remnants, a sort of living testimony, of a pristine way of life of hunting and gathering, submerged elsewhere by pastoralism and agriculture. This approach is all the more strengthened when the group in question is not only ecologically, economically, and culturally deviant from the mainstream of the surrounding populations but also linguistically apart. In this view, huntergatherers are supposed to be "cultural survivors" precisely because they are, or are considered to be, "linguistic survivors." Their origin, it is claimed, can be traced following a classical genealogical tree, leading from an original starting point all the way down to present times. We call this a top-down model.

Taken to its extreme consequences, a startling example of this approach is Nurse's (1986) reconstruction of the past history of the Dahalo, a group of about 300 people living along the coastal forest strip of northern Kenya, not far from Lamu: traces of Dahalo presence (in the form of possible loans) are traced by Nurse as far as the Central Kenya Highlands. The contrary hypothesis, i.e., that many of them were loanwords into Dahalo (while a majority of putative Dahalo loans were probably the product of casual resemblance) was not taken into consideration. The result is a fascinating but utterly unprovable historical reconstruction, where the hunter-gatherers of today are the last representatives of prehistoric groups assimilated by advancing pastoral and agricultural peoples, like the tips of sunken islands.

Of course, there are other, less controversial cases to which a top-down model may apply. In Tanzania, the Hadza and the Sandawe may be instances of longtime ethnic groups united by, inter alia, hunting and gathering as an economic way of life, and stubbornly resisting assimilation. What is certain, on the other hand, is that in many other cases a top-down model, at least in its extreme form, cannot be applied successfully, and a different line of analysis is needed. 
The second approach has the hunter-gatherers as marginal groups, and often as former pastoralists who were forced to adopt a despised way of subsistence after having lost their cattle as a result of war or epidemics. Such a view receives further support by the observation that the marginal, outcast groups of East Africa are constantly renewed and enriched through the influx of genetic (and very possibly linguistic) material coming from neighboring peoples: individuals, either men, women, or children, may and often are cast off of their group for a number of reasons, mainly having to do with the infringement of group solidarity and codes (Stiles 1988). There is no single starting point, and a genealogical tree is ill suited to represent the genesis of these groups. This model of analysis can be called "bottom-up."

The two models owe their existence to opposite frames of mind, each of them suiting different interests and methodologies. In a way, they are therefore irreducible to each other. On the other hand, it is well possible to imagine the models as extreme points along a continuum, with extreme and moderate cases. We can imagine, e.g., an original group getting "reinforced" and renovated from time to time through new ethnic and linguistic material.

In this chapter, we will argue that a bottom-up model may better account for the ethnic and linguistic history of the Ongota, and possibly - but certainly not all! - of other hunter-gatherers of East Africa. As detailed in the text that follows, the Ongota have largely replaced their ancestral language with the Cushitic language of their pastoral neighbors, the Ts'amakko, while a bare handful of elders still speak the Ongota language, which is so different from neighboring Cushitic and Omotic languages that it has so far resisted classification. In another radical example of a top-down approach, Fleming (2006) has recently claimed that Ongota represents a separate branch of the Afroasiatic phylum - therefore dating back thousands of years. This hypothesis may be matched at the ethnographic level with the (completely unwarranted) suggestion, found in a travel report from 1896 (Donaldson Smith 1896), that the Ongota are the remnants of an archaic pygmy population of hunter-gatherers.

The Ongota are still fairly unknown - a kind of "new entry" in the world of hunter-gatherer communities - and the problems surrounding their language and past history are very complex indeed. The following sections will present in more detail the Ongota and the ethnolinguistic evidence pointing to their origin.

\subsection{The Ongota}

The Ongota (known locally mainly as Birale) are a tiny population of about 100 living in southwestern Ethiopia. Their only village, Muts'e, is found along the Weyt'o River, some 35 minutes walking distance from the bridge along the road leading from Konso to the Omo Valley. ${ }^{1}$ The village is within the territory of the Ts'amakko (or Tsamai), who speak one of the Dullay varieties of East 


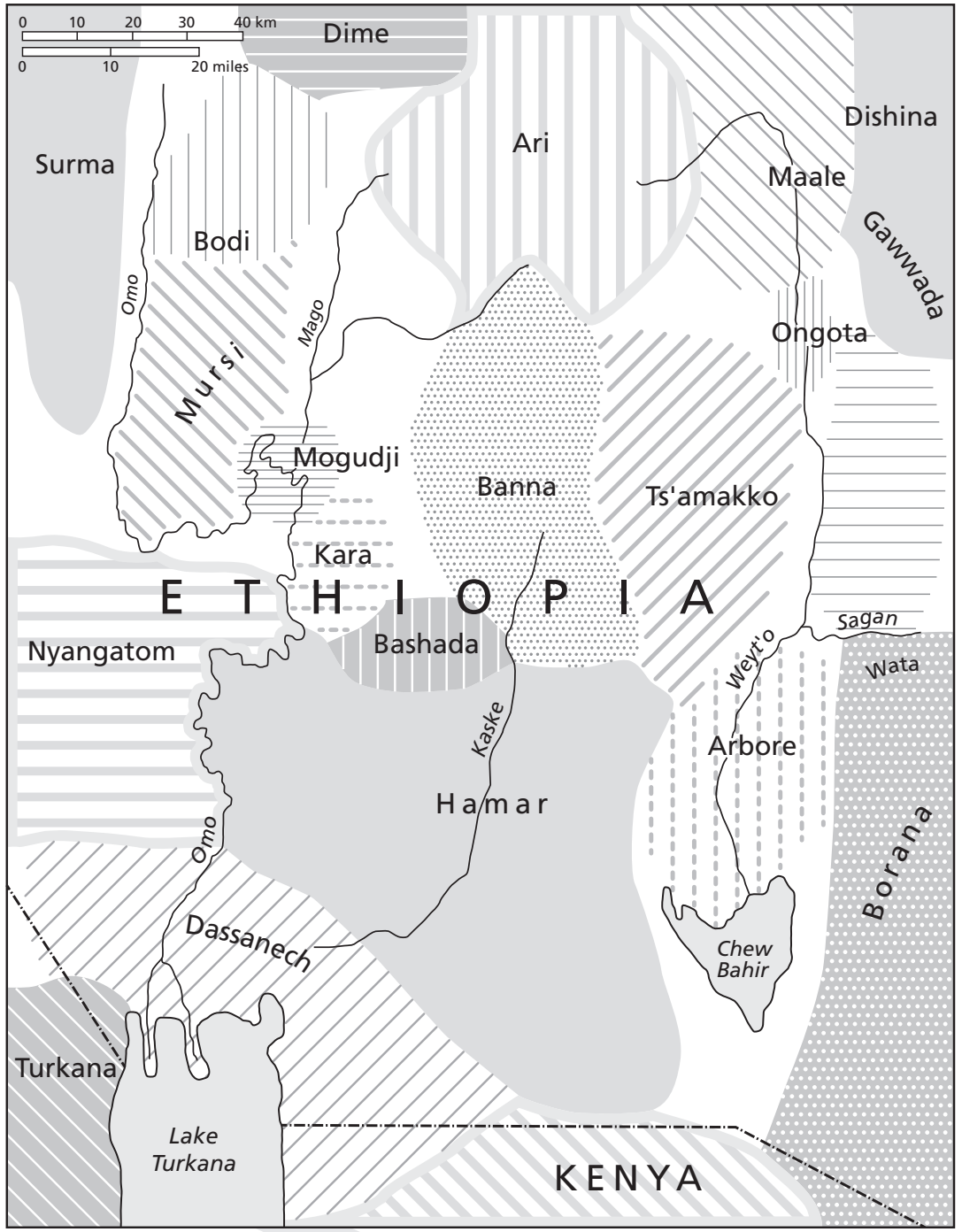

Map 5.1 The Ongota and the neghboring peoples mentioned in the text. (Adapted with changes from: www.southethiopiaresearch.org/).

Cushitic (Savà 2005). Other neighboring populations are the Gawwada and other Dullay-speaking groups to the east, the Maale to the north, and the Arbore to the south (see Map 5.1). All their neighbors speak East Cushitic languages, except for the Maale, whose language is North Omotic. Additional groups in 
contact are the Hamer, the Banna (both South Omotic speakers), the Konso and the Boraana (East Cushitic speakers).

The Ongota are known in the area for their linguistic and ethnographic uniqueness. Their traditional language, called Piifa Songota, is different from any other language in the area. Actually, it is so different as to be still unclassified, although many proposals have been put forward.

Ongota is also a very endangered language, as the community speaks Ts'amakko for everyday communication. This is also the language taught to children. About ten elders still have a knowledge of the Ongota traditional language (Fleming et al. 1992/93; Savà and Tosco 2000; Fleming 2006).

Ethnographically, the Ongota are described as the only hunter-gatherers in an area characterized largely by the so-called "cattle complex." They practice fishing, hunting, collecting wild plants, as well as apiculture. However, they essentially live on cultivated maize and vegetables and keep some chickens, goats, and sheep. They are also good producers of bananas, which together with honey are marketable goods. Today the Ongota are socially dominated by the Ts'amakko. The influence is so strong that it is hardly possible to find any Ongota cultural trait that is not derived from the Ts'amakko. The two groups intermarry and the Ongota take part in the weekly Ts'amakko market in Weyt'o town.

\subsection{The Hunting-Gathering Origins of the Ongota}

One may ask why the Ongota are considered hunter-gatherers if they cultivate and have domestic animals. They are not even distinguished by special nonagropastoralist activities, as these are not exclusively Ongota in southwestern Ethiopia. Most of the surrounding people hunt, collect some plants, and produce honey, and, as is well known, hardly any community survives by eating exclusively wild animals and plants; food is always produced from some sort of small-scale agriculture and cattle-keeping. Fishing is the only practice that the Ongota do not share with neighboring peoples; actually, Ongota are the only group for which fish is not a taboo food.

This does not necessarily mean that the Ongota were originally huntergatherers and have absorbed alternative forms of food production. Alternatively, they might have had a pastoralist past and for some reason gave up animal husbandry. There are some indications supporting this view. Savà and Thubauville (2010) have found out that older Ongota women have no special knowledge of wild plants. This may help proving that the Ongota are not originally hunter-gatherers. According to Melesse Getu (1997), and as confirmed by the Ongota themselves to Savà and Thubauville in 2006, a massive presence of the tse-tse fly (the biological vector of trypanosomiasis) 
along the Weyt'o River prevents Ongota from breeding cows. For this reason the only domestic animals the Ongota breed are goats and sheep, beside chickens. This may suggest a bottom-up approach, one in which the Ongota were earlier pastoralists forced to give up cattle-keeping, but also, on the opposite side, the incomplete acculturation of a hunter-gatherer group. The whole story, it will be suggested, is much more complex.

Still, according to Melesse Getu (1997), the presence of firearms in the forest of the Weyt'o River Valley and desertification resulted in drastic impoverishment of fauna and flora. Moreover, the number of fish had decreased during the last years - the main reason being the building of a dam that served the irrigation system of a large cotton farm near the village of Weyt'o and through which few fish could pass. This means that environmental conditions might have posed serious problems for the Ongota if their life was based mainly on hunting and gathering.

The solution to the Ongota dilemma - where do they come from, and what have they been in the past? - might come from the analysis of some, largely unpublished, historical information. In the following paragraphs we will use them to support a bottom-up model for the understanding of the Ongota huntergatherer status.

\subsection{Internal Evidence: The Myth of the Ongota Origins}

The Ongota have a traditional history regarding their origins. This has been recorded, but not published, by Savà and Tosco (2000, 2006). The storyteller was Mole Sagane, the former chief of the community. Until his death in January 2008 he was a respected and charismatic elder and one of the last few speakers of the Ongota traditional language.

The story tells that the original Ongota group was living in the Maale area. They were killing and stealing cattle using sticks with poisoned tips. Apparently, they already were composed of different sections, each one going back to a different people, ranging, for example, from the North Omotic Maale to the South Omotic Banna, to the East Cushitic Borana and Dishina.

They were eventually chased away and forced to move southward along the Weyt'o River. The people started walking along the riverbed and eventually found their way blocked by a large boulder. The people asked the wisest men of each clan how to break it apart. All of them tried their divinations, but to no avail. After the wise men failed, someone suggested asking a small boy to try. They chose one and gave him a rhino's horn. The boy touched the boulder with the horn and it immediately split apart. The Weyt'o River could flow southward and the Ongota could move on.

The Ongota followed the river until its end (the Weyt'o river runs dry somewhere to the South of the Ongota settlement in semidesert areas), where 
Table 5.1 Origin of the Ongota clans

\begin{tabular}{ll}
\hline \hline Clan & Origin \\
\hline baritta & Boraana \\
ozbikko & Arbore \\
Samaddo & Gawwada \\
reegakko & Dishina \\
hizmakko & Maale, Gabo, Hamar and Boraana \\
\hline \hline
\end{tabular}

they met the Arbore people. After staying there for some time, they were again forced to move, this time northward, until they settled in the general area where they are found nowadays.

It is interesting to note that the wizards of each section - i.e., of the different peoples - fail to split the boulder, but a child does. One could interpret this as the symbolic expression of a new ethnic identity. Only the Ongota could set the river free, not the original peoples as represented in the tribal sections. The myth, centered as it is on the Weyt'o, may be seen as the Ongota version of the hunter-gatherer topophilia: it certainly symbolizes the strong symbiotic link between the Ongota and the river. While the pastoralists exploit the land beyond the riverbanks, it is the Ongota who really live around and from the river: from it the Ongota get their identity.

From the myth one can see that the Ongota consider themselves a mixture of people coming from surrounding communities. Each Ongota clan retraces its origin from one population, except one that claims four separate connections (Table 5.1).

It is interesting to note that a claimed multiethnic origin is not at all unknown in the area. Further to the west, along the lower course of the Omo, the Dhaasanac have a partially similar story, although the bulk of the Dhaasanac claim to derive from the south and to have submerged a local population of fishermen (Tosco [2007], following and elaborating Sobania [1980]). If further research will show that the multiethnic origin has actually an ideological basis in the area, it will be possible to analyze this part of the Ongota myth of the origins as an adaptation of their history to a pattern common among the neighboring pastoralist peoples. This adaptation is also evident from the names of the clans, which are found among the Ts'amakko and the Gawwada (and possibly other groups, although relevant data are missing in this regard).

We have seen that the myth embraces two aspects of the origins of the Ongota: their geographic origin, which is claimed to be strictly local, centered on the Weyt'o River, and their ethnic composition, which is reported as multiethnic from the very beginning. The local geographic 
origin of the Ongota is compatible with a top-down model (the Ongota as the pristine inhabitants of the area), while the multiethnic origin points to the bottom-up approach. Of course, even the plurality of ethnic origins does not exclude a priori the existence of an original, nuclear group of huntergatherers, and the strength of the myth as a proof is further weakened by its not uncommon character. Still, at least two points seem to be clear and cannot be dismissed: the Ongota themselves do not consider themselves as the first inhabitants of the area and do not see themselves as original huntergatherers.

\subsection{External Evidence: Old Contacts with the Maale}

The Maale are highland pastoralists, living to the north of the Ts'amakko and the Ongota in an area ranging in altitude from about 1,000 to 2,800 meters above sea level (Azeb Amha 2001: 1). The Ongota myth of origin shows that they used to live among the Maale. Other pieces of information confirm this early relation: the Ongota reported to Savà and Thubauville (2006) that they moved often in their (recent?) history. They still remember the names of about thirty settlements they settled and abandoned. The first are located north of their present location, toward the Maale highlands. The present one, Muts'e, is on the Weyt'o River. Before Muts'e the Ongota were living in Aydolle, which is the village visited in 1991 by a few members of the team who authored Fleming et al. (1992). The place lies just some hundred meters from Muts'e toward the forest. A few abandoned huts can still be recognized.

A Maale tradition about the Ongota was collected by Sophia Thubauville in November 2007. Contrary to the Ongota myth of origin, the Maale say that the Ongota were once part of the Maale. To the northeast of the Maale territory there is also a place called Ongo. Maale people still go and dance there to celebrate a good harvest. There is a good memory of the Ongota, and the Maale are proud to know that an offspring of their community can be found somewhere along the Weyt'o River.

We also owe a few interesting pieces of information to the American traveler Arthur Donaldson Smith, who visited southwestern Ethiopia at the end of the nineteenth century. The following excerpts of his report are relevant to our discussion:

'We came to a large and warlike tribe called the Arbore, inhabiting half of the valley above Lake Stephanie...'

[talking about the people that they heard of] They were Burle, Dume, Mali, Borali in succession towards the north, and then the Bunno, Dime, Ario, and Amar to the west (Donaldson Smith 1896: 224). 
'Dume, Mali and Borali are pygmies. The Dume conquered the Burle eight years before.' [emphasis ours]

Several populations listed by Donaldson Smith in the preceding quotes and elsewhere can still be found in southwestern Ethiopia. Not so with the Burle, Dume, and Borali. Fleming et al. (1992) proposed connecting the name Borali to Birale, which is the ethnic name presently given to the Ongota by neighboring populations. This would imply, once again, that according to Donaldson Smith the Ongota were living North of the Maale area (referred to as "Mali" by Donaldson Smith). Map 5.2, created by Sophia Thubauville, reconstructs the movement of the Ongota from the Maale area to their present location. Only the

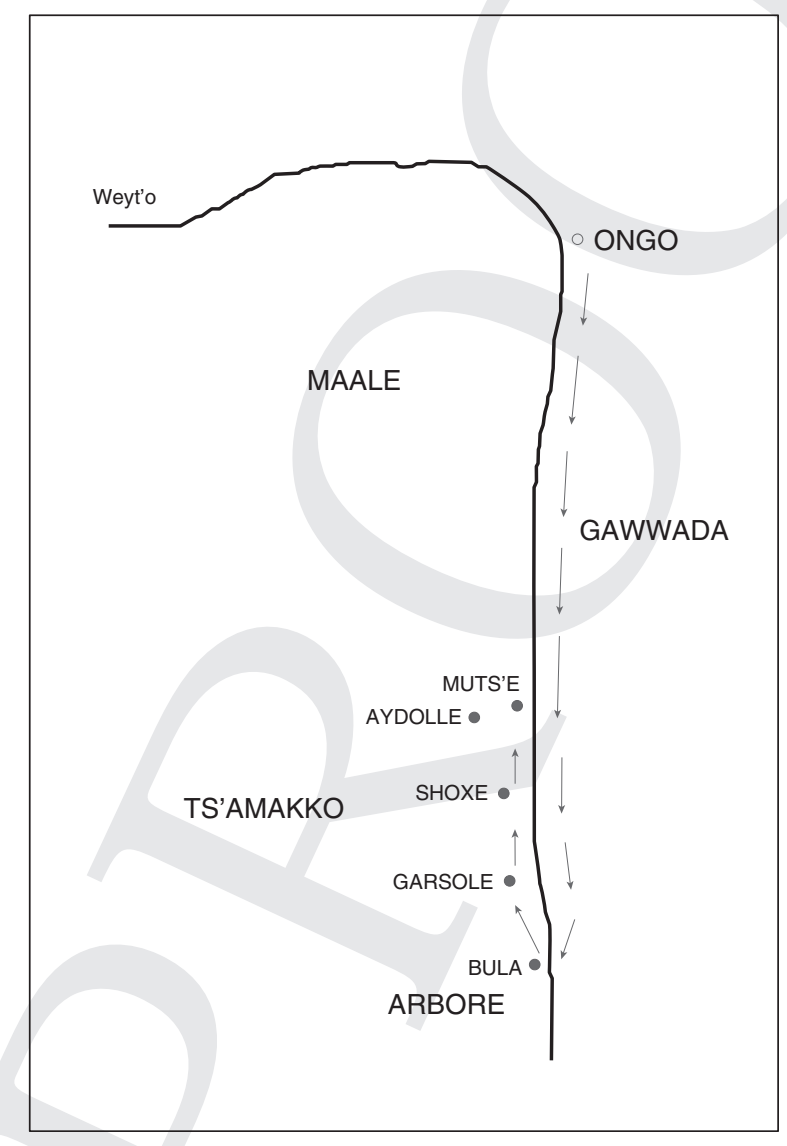

Map 5.2 The movements of the Ongota along the Weyt'o River, according to the Ongota myth of the origins (by Sophia Thubauville). 
places that could be localized with the help of Maale and Ongota people are shown.

\subsection{The Ongota as a Marginal Group}

In contradiction to Fleming's (2006) view, according to which the Ongota were once a much more powerful population in the area (an idea strikingly similar to Nurse's 1986 reconstruction of the Dahalo past in Kenya; see earlier), we believe that the present assimilation of the Ongota to the Ts'amakko and the early affiliation to the Maale are just the two most recent episodes in a long history of Ongota subordinate relations with dominant populations of the area. From each dominant group the Ongota have assimilated cultural traits and linguistic elements.

Similarly, the Boni of the Kenya-Somali border (Tosco 1994) have preserved, with due changes, the South Somali dialect of their previous "masters," the Garre - even though they are politically dominated today by the Oromo. The ethnonym Boni, an adaptation of Somali boon "hunters," nowadays widely used in Kenya (Heine 1977), is matched by a parallel denomination as Waata among the Oromo and as Aweer $\sim$ Aweera in the group itself; all these terms simply mean "hunters." All these ethnonyms indicate that, at least since the split from the Somali, one is confronted with an occupational group that is also a separate ethnolinguistic entity.

Just south of the Boni, the Dahalo speak a Cushitic language (either of the southern or the eastern branch) but a very limited portion of the vocabulary (approximately fifty words) contains a nasalized dental click $(/ \mathrm{l} / /$; cf. Maddieson et al. [1993] for a phonetic analysis of Dahalo), and this may be interpreted as a very old lexical layer: obviously, the very presence of a phonological click in an otherwise orthodox Afroasiatic language may suggest that we are dealing here with the "original" layer, and the only surviving evidence of what was once a Khoisan language. In its turn, this would also be the northernmost relic of the original Khoisan-speaking population of East Africa, prior to the advent in the area of food production (Tosco 1991, 1992). The extreme top-down model expressed by Nurse (1986) and briefly discussed in Section 5.2 seems to follow naturally from such an interpretation. Of course, there is at least a huge obstacle to the whole idea: the very existence of Khoisan as a genetically valid group is today more and more rejected (Güldemann and Voßen 2000). ${ }^{2}$

All these cases indicate that change of linguistic and ethnic affiliation seems indeed to be quite common in the area, for hunter-gatherers and pastoralists alike (cf. Tosco 1998 for an analysis of such changes in terms of the catastrophe theory).

Coming back to the Ongota, it could well be retorted that, as was seen earlier, the Maale consider the Ongota to have been "a part" of their people, which 
could lend support to the hypothesis that they were actually pastoral peoples driven for unknown reasons to hunting and gathering. But an outcast group is still "part of a people," which in this part of East Africa means being bound by ritual and legal obligations and economic interests, and not by a putative common ethnic origin or linguistic behavior (cf. again Tosco 1998). Similarly, occupational minorities of Ethiopia are still part of an "ethnic group" while being heavily marginalized: indeed, cultural assimilation and subordination to a dominant group distinguish the social history of the outcast groups all over southern Ethiopia (cf. Freeman and Pankhurst 2001), and possibly beyond because the largely unknown outcast groups found among the Somali seem to share a similar history. All these groups are characterized by their skill in handcraft and the power of manipulating clay, iron, and hide give them supernatural attributes. For this reason they are very useful, but despised and feared at the same time. Marriage with an outcast person, for example, is forbidden or at the very least frowned on. The Ongota are not specialized in any handcraft; there is, however at least one indication that in the past they might have been attributed some magical power. During their stay in the South Omo area in 1973 Jean Lydall and Ivo Strecker heard "some interesting news of people called the Birale who live on the east of the Birale mountain, close to the river. The Tsamai refer to them as hajje ${ }^{3}$ and consider them to be powerful magicians" (Lydall and Strecker 1979: 111). Because they do not keep big herds of cattle and have a strange traditional language of their own, the Ongota are looked on in scorn by the neighboring pastoralist groups (Savà and Tosco 2000: 65). On the other hand, they are allowed to intermarry with the Ts'amakko and the Gawwada. In the context of these ambiguous social relations with their neighbors, the Ongota will most probably decide to abandon for good their status of a socially despised group by starting keeping cattle and becoming a full pastoralist people. They eventually might be accepted as a new Ts'amakko clan, thus completing the assimilation process.

\subsection{Ongota: An Unclassified Language}

As mentioned earlier, the traditional language of the Ongota, called Piifa Songota, is different from all other languages in the area, which are from the Cushitic and Omotic subgroupings of Afroasiatic and from the Surmic subgrouping of Nilo-Saharan. To explain this uniqueness, the top-down model suggests that the Ongota language is genetically a linguistic isolate spoken by a hunter-gatherer group. Our idea, instead, is that Ongota's complex history of domination by different groups is reflected in the language, with different superimposed strata. The linguistic import of the constant influx, of different individuals, families, and maybe whole sections, resulted in a language that is 
very deviant form any other language in the area, to the point of being unclassified.

From the morphological point of view, the language is strikingly different. It shows an uncommonly poor and isolating morphology: gender and number have no formal expression on nouns; there are no person and tense verbal suffixes; expression of tense is based on tonal accent change. Moreover, the relatively few grammatical elements have forms not attested in the area: morphological exponents, such as deictic suffixes, determiner suffixes, adjectival endings, and most verbal derivation extensions. Also items belonging to other word classes, such as pronouns, adjectives, adverbs, clitics, and postpositions cannot be etymologically linked to any neighboring group.

One of the most interesting distinctive morphological features is the absence of verb inflection, which is so characteristic of neighboring Cushitic and Omotic languages. The subject is indexed only by preverbal pronominal clitics. Tense is expressed by placing the tonal accent on the rightmost syllable of the verb, in which case the tense is past, or in the preceding one, in order to express non-past tense. The non-past position of the accent in monosyllabic verbs is on the pronominal clitic. This is shown in the following examples.

\section{Example 5.1: Past}

(1) cata $k a=c a ́ k$

meat $\mathrm{I}=$ eat.PAST

I ate meat

\section{Example 5.2: Non-Past}

(2) $c a t a ~ k a ́=c a k$ meat $\mathrm{I}=$ eat.NON-PAST

I eat/will eat meat

As far as we know, the closest parallel is found in Hamer, a South Omotic language spoken not far from Ongota to the West. Verbs in Hamer are not inflected for the person of the subject, which is indexed by means of preverbal clitics (Cupi et al. 2013). On the other hand, Hamer has a complex system of aspect and tense suffixes, many of which probably derive from old copula elements.

Considering the area in which it is spoken and the typology of neighboring languages, one would also expect Ongota to have a rich nominal morphology. Instead, the language does not show any trace of the complex Cushitic and Omotic system of number and gender. For example, in Ts'amakko a basic noun can be derived for singulative and plurative by means of derivational suffixes: from the noun kar-o "dog," one can obtain kar-itto "one male dog," kar-itte "one female dog," and kar-re "dogs." Ongota operates with a simple singular/ plural opposition. Plurality, moreover, is either lexicalized (for instance: ayma 
"woman"/ aaka "women") or expressed by the word bad'd'e "many," following the noun (kara bad'd'e "fishes").

There is no published work devoted to comparative Ongota morphosyntax. Some notes are found in Blažek (1991, 2001, 2005), Savà and Tosco (2003), and Fleming (2006). Among the proposals for a classification, Blažek finds similarities in the pronominal series between Ongota and some Nilo-Saharan languages, while Savà and Tosco adopt the more conservative view that Ongota is an East Cushitic language of the Dullay subgroup on the basis of some tone accent similarities in verbs. One should also mention that Aklilu Yilma (p.c.) sees in Ongota's poor morphology an indication that the language is a creolized pidgin. He supports this view with the local legend of the multiethnic origin of the Ongota that we mentioned earlier.

Most of the Ongota comparative studies have focused on lexicon. This is characterized by a mass of Ts'amakko loanwords that entered the Ongota recorded from the last speakers. Among them one could also find words from other Dullay varieties. According to Fleming (2006), however, for the Ts'amakko-like words belonging to some core and cultural lexicon the direction of borrowing could have been the opposite - from Ongota into Ts'amakko.

The proportion of Ts'amakko/Dullay and non-Ts'amakko/Dullay lexicon in Ongota can be calculated using the best comparison of the Ongota lexicon published so far (Blažek 2005): the Ts'amakko/Dullay list consists of 295 parallels, while parallels with neighboring Cushitic (such as Oromo and other East Cushitic languages) and Omotic (such as Hamer and other South and North Omotic languages) adds up to only about fifteen entries each. In his article Blažek considers each classified group of words as a lexical stratum. In his opinion, the oldest has Nilo-Saharan origin; he himself had isolated the similarities with Nilo-Saharan languages in an older paper published only recently (Blažek 2007).

There have been other attempts at Ongota classification by lexical comparison:

- Bender (1994) lists Ongota as "unclassifiable" because, according to his lexicostastistic technique, it shares less than $5 \%$ with any other language. However, he later defined Ongota as "hybridized Cushitic" (p.c.).

- Fleming (2006) has proposed that Ongota is Afroasiatic, although a separate branch of it, on a par with, say, Cushitic, Berber, or Semitic.

- Ehret (p.c. 2002), on the basis of unpublished comparative work, favors a South Omotic affiliation.

The following section will show why all these proposals are unsatisfactory. 


\subsection{Traces of Contact in the Ongota Language}

The uncertainty on the genetic status of Ongota tells us that the classification of Ongota is a very hard, perhaps unfeasible, task. All the proposed hypotheses are very interesting, but do not provide definite evidence, and all the attempts share the methodological pitfall of not being based on a reconstruction of Ongota. Many similarities and relevant etymologies therefore look very impressionistic and may be put into question (see Savà and Tosco [2007] for a critical appraisal of the reconstructions in Fleming [2006]).

Savà and Thubauville (2010) have also tried to classify a corpus of Ongota lexemes. Their aim was not to propose another classification, but to spot the linguistic traces of contact between the Ongota and the groups that they most likely met during their journeys. Their corpus consists of a selection of about 700 Ongota lexical items, much larger than the one used by Blažek. The words come from Savà and Tosco (2000) with some integration from Fleming et al. (1992/93). To accept a borrowing Savà and Thubauville (2010) required a particularly high and unquestionable level of similarity. Whenever possible, the comparisons have been checked against Blažek (2005) and Fleming (2006).

\subsubsection{Ts'amakko Borrowings}

About 200 words are Ts'amakko borrowings. Some of them appear unchanged in Ongota, while others show phonological and morphological adaptation. A few Ts'amakko loanwords that are preserved unchanged are listed in Table 5.2.

\begin{tabular}{|c|c|}
\hline Ongota & \\
\hline Ongota and Ts'amakko & Gloss \\
\hline game & corn \\
\hline$g e ?$ & to belch \\
\hline gufa? & to cough \\
\hline kol & to come back, return \\
\hline komba & beads necklace \\
\hline malal & to be tired \\
\hline middo & bracelet \\
\hline sarba & calf \\
\hline siibde & bow string \\
\hline tilile & black kite \\
\hline laaxko & wooden arrow \\
\hline palde & iron arrow \\
\hline
\end{tabular}


Table 5.3 Vowel length reduction

\begin{tabular}{lll}
\hline \hline Ongota & Ts'amakko & Gloss \\
\hline dig & diig & to pour \\
bositte & boositte & hair of chest \\
\hline \hline
\end{tabular}

Table 5.4 Vowel height change

\begin{tabular}{|c|c|c|}
\hline Ongota & Ts'amakko & Gloss \\
\hline gunture & gontore & eland \\
\hline merja & mirja & kudu \\
\hline
\end{tabular}

Table 5.5 Dental assimilation of glottal stop

\begin{tabular}{lll}
\hline \hline Ongota & Ts'amakko & Gloss \\
\hline $\begin{array}{l}\text { moqotte } \\
\text { oršatte }\end{array}$ & $\begin{array}{l}\text { muq'o?te } \\
\text { orša?te }\end{array}$ & frog \\
\hline \hline
\end{tabular}

Table 5.6 Nasal Change

\begin{tabular}{lll}
\hline \hline Ongota & Ts'amakko & Gloss \\
\hline kunkumitte & kumkumitte & cheek \\
\hline \hline
\end{tabular}

The phonological makeup of some Ts'amakko words has been slightly changed. Typical adaptations include vowel length reduction, vowel height change, dental assimilation of glottal stop, and nasal change (Tables 5.3-5.6).

In some words, final $/ a$ /replaces the Ts'amakko gender suffixes - $o(\mathrm{M})$ and - $e$ (F) (Table 5.7).

The Ts'amakko singulative suffixes are generally lost in Ongota. In the examples in Table 5.8, a final /a/appears in place of the masculine singulative suffixes $-k o$, $-a k k o$ and -atto.

In Table $5.9 \% /$ may appear instead of the feminine singulative suffix -te.

The example in Table 5.10 shows the deletion of the masculine gender suffix $-k o$ and no replacement.

The derivation passive suffixes -am has been absorbed in the stem in Table 5.11. 
106 Graziano Savà and Mauro Tosco

Table 5.7 Gender suffix replacement in Ongota

\begin{tabular}{|c|c|c|}
\hline Ongota & Ts'amakko & Gloss \\
\hline baara & baaro & armpit \\
\hline $\operatorname{irga} a$ & irgąo & axe \\
\hline ћeka & ћeeko & chest \\
\hline qola & q'ole & animal (domestic) \\
\hline kirinca & kirince & ankle \\
\hline kurruba & kurrube & crow, raven \\
\hline
\end{tabular}

Table 5.8 Masculine suffix replacement in Ongota

\begin{tabular}{lll}
\hline Ongota & Ts'amakko & Gloss \\
\hline
\end{tabular}

Table 5.9 Feminine suffix replacement in Ongota

\begin{tabular}{lll}
\hline \hline Ongota & Ts'amakko & Gloss \\
\hline halo & haal-te & calabash cup \\
\hline \hline
\end{tabular}

Table 5.10 Suffix loss with no replacement in Ongota

\begin{tabular}{lll}
\hline Ongota & Ts'amakko & Gloss \\
\hline & bor-ko & stomach \\
\hline
\end{tabular}

Table 5.11 Suffix absorption in Ongota

\begin{tabular}{lll}
\hline \hline Ongota & Ts'amakko & Gloss \\
\hline wuyyam & $\begin{array}{l}\text { wuyy } \\
\text { wuyy-am }\end{array}$ & $\begin{array}{l}\text { to call } \\
\text { to be called }\end{array}$ \\
\hline
\end{tabular}


Table 5.12 Internal and final changes in Ongota

\begin{tabular}{|c|c|c|}
\hline Ongota & Ts'amakko & Gloss \\
\hline gawarsa & gawarakko & bateleur (Theratopius ecaudatus) \\
\hline mirila & mirille & cheetah \\
\hline sayra & sawro & dik dik \\
\hline
\end{tabular}

Table 5.13 Irregular consonant change in Ongota

\begin{tabular}{|c|c|c|}
\hline Ongota & Ts'amakko & Gloss \\
\hline tala $a$ & sala $\hbar$ & four \\
\hline luqqa & lukkale & chicken \\
\hline
\end{tabular}

Some borrowings show word internal and final changes (Table 5.12). Irregular consonant change is found in at least two cases (Table 5.13).

\subsubsection{Non-Ts'amakko borrowings}

Only forty items are considered as borrowings from neighboring languages and language groups. A selection of those with the highest level of similarity with the geographically closest languages is shown in Table 5.14.

Casual lookalikes between unrelated languages can always be found and they can easily get in the way of language comparison; thus, we find at least a couple of similarities with different Nilo-Saharan languages (Table 5.15).

Justifying the presence of these resemblances as due to anything else than other sheer similarity is very difficult because the languages are spoken as far away as the Sudan. Also accepting Blažek's idea that Ongota is originally a Nilo-Saharan language does not make matters much easier, as the languages belong to different Nilo-Saharan subgroups. Moreover, Nilo-Saharan subgrouping, and the very existence of Nilo-Saharan as a linguistic family, are of course a debated matter.

According to Blažek (2005), there are also borrowings from South Cushitic languages. Three of them are particularly interesting (Table 5.16).

Also in this case it is not likely that the Ongota borrowed words from languages spoken as far away as Tanzania; on the other hand, Dahalo could actually be East Cushitic (as argued for by Savà and Tosco 2000), and therefore Ongota might have borrowed from an unknown and closer-to-hand East Cushitic language.

There are other cases in which similarities are shared by more members of a subgroup (Table 5.17). 
Graziano Savà and Mauro Tosco

Table 5.14 Non-Ts 'amakko borrowings in Ongota

\begin{tabular}{lll}
\hline \hline Ongota & Hamer (South Omotic) & Gloss \\
buusa & busa & belly \\
adab & atab & tongue \\
laba & laba & wide \\
ooma & oom & bow \\
gas & ga? & bite \\
Ongota & Ari (South Omotic) & Gloss \\
goola & goola & local beer \\
wanna & waanna & good \\
Ongota & Maale (North Omotic) & Gloss \\
na?a & na?i & child \\
baliti & baliti & forehead \\
toiti & toiti & eldest son \\
Ongota & Borana (East Cushitic) & Gloss \\
arba & arba & elephant \\
meela & miila & leg \\
olla & olla & village \\
Ongota & Konso (East Cushitic) & Gloss \\
aama & ama & breast \\
armata & armayta & mucus \\
\hline \hline
\end{tabular}

Table 5.15 Ongota similarities with Nilo-

Saharan languages

\begin{tabular}{lllll}
\hline \hline & \multicolumn{3}{c}{ Nilo-Saharan Language } & \\
\cline { 2 - 3 } Ongota & Mimi & North Mao & Kanuri & Gloss \\
\hline $\begin{array}{l}\text { maara } \\
\text { itima }\end{array}$ & maar & meri & timi & $\begin{array}{l}\text { boy } \\
\text { tooth }\end{array}$ \\
\hline \hline
\end{tabular}

Table 5.16 Ongota borrowings from South Cushitic

\begin{tabular}{|c|c|c|c|c|c|}
\hline \multirow[b]{2}{*}{ Ongota } & \multirow[b]{2}{*}{ Gloss } & \multicolumn{3}{|c|}{ South Cushitic Languages } & \multirow[b]{2}{*}{ Gloss } \\
\hline & & Dahalo & Iraqw & Burunge & \\
\hline $\begin{array}{l}\text { c'asaw } \\
\text { q'umo } \\
\text { c'asa }\end{array}$ & $\begin{array}{l}\text { water } \\
\text { container } \\
\text { stone }\end{array}$ & tl'ááca & $\begin{array}{l}\text { qumi } \\
\text { tl'aSa-nu }\end{array}$ & tl'asu & $\begin{array}{l}\text { river, lake } \\
\text { traveling gourd } \\
\text { stone }\end{array}$ \\
\hline
\end{tabular}


Hunters and Gatherers in East Africa

Table 5.17 Similarities with Oromo dialects, Konsoid and North Omotic languages

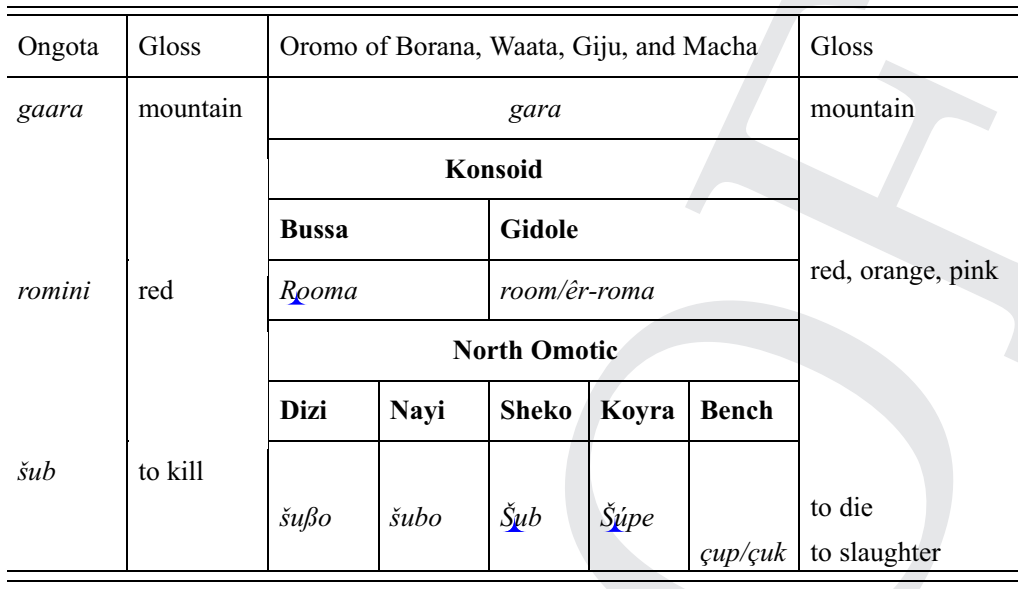

Table 5.18 Words with no apparent similarity in other languages

\begin{tabular}{ll}
\hline \hline fa? & to add \\
dabaša & baboon \\
tip & to die \\
xa? & to do \\
howwa & ear \\
cak & to eat \\
na? & to give \\
noqot & to look at \\
miša & name \\
axaco & sun \\
binta & wild animal \\
\hline \hline
\end{tabular}

Last, we have Ts'amakko loanwords shared by other Dullay dialects; it seems safer to consider all of them borrowed into Ongota through the intermediacy of Ts'amakko - also on the basis of the fact that there are no cases of Dullay lexemes in Ongota not shared by Ts'amakko.

\subsubsection{Unclassified Words}

The majority of the words taken into consideration by Savà and Thubauville resist classification, and therefore may suggest an ancient hunter-gatherer 
group with a yet unknown linguistic affiliation. Some examples of these unaffiliated words are shown in Table 5.18.

\subsection{Conclusions}

In our opinion, the Ongota myths of origin and the traditions of their northern neighbors, the Maale, seem to lend support to a bottom-up approach, although other historical scenarios are not logically excluded. The main points are:

- The Ongota are the descendants of different peoples - or better, of various sections of peoples - who joined together. The Ongota clan names are in effect the same, apparently, as those found all over the area.

- The Ongota lived originally to the north of their present location, in the territory of the Maale (an Ometo-speaking - i.e., North Omotic - group).

- The Ongota were engaged in stealing cattle at the expenses of the Maale.

- The Ongota forced their way (or were forced to move) southward along the Weyt'o River and have lived in close association with it since then.

- Ongota women do not have any special knowledge of wild plants collection.

- The Ongota cannot keep cattle because of the presence of the tse-tse fly in the area.

The Ongota are presently assimilating to the Ts'amakko pastoralists; recently and still marginally, a few Ongota even bought goats (which nevertheless are not kept in the Ongota village but in Weyt'o town, where several Ongota have been taken residence). From a linguistic point of view, the current terminal state of the Ongota language has been mentioned, while from a cultural point of view the Ongota are certainly hardly distinguishable from their pastoral neighbors. No reliable data on the Ongota economy are available, although economic assimilation to the Ts'amakko has so far been hampered by the absence of cattle, or, in other words, of "hard currency."

The traditional language of the Ongota reflects their contact history. Continuous influence from different languages resulted in a very divergent language with an unusual isolating character and a unique lexicon. The presence of a good number of Ts'amakko loanwords shows the particularly strong relation with the people speaking this language. We assume that the same happened with other groups to which the outcast Ongota were affiliated.

The presence of a fairly substantial number of unclassified words (as seen in Section 5.9.3) yields plausibility to the possibility of an original hunter-gatherer group which came in contact with a number of different peoples and languages, to the point of radically changing its language affiliation. This would make the Ongota resemble a bit both the Dahalo and the Boni of Kenya (discussed in Section 5.7): just like the Dahalo, the Ongota would 
have preserved a tiny lexical layer of their original language, and just like the Boni they would have shifted their language to that of their dominating language group (the present one - the Ts'amakko - in the case of the Ongota; a former one - Southern Somali Garre - in the case of the Boni). Nothing among the meager available data seems to force such an analysis, and just like for all the other hunter-gatherer groups it is close to impossible to detect the full range of the prehistoric contacts. Weighting the pros and cos of competing models, we opt in the end for a bottom-up approach: it seems to better fit the present situation on a number of counts: the language, the sociology of the Ongota, and their traditions. The simplest (albeit maybe less fascinating) scientific hypothesis remains to project the present state of affairs in the past and to conclude that the Ongota are not a remnant hunter-gatherer population. They were originally an outcast community that has been wandering in the area around the Weyt'o River and affiliating itself in the course of time to different dominant pastoralist groups. They are presently attached to the Ts'amakko, but full assimilation is not possible at the moment because the Ongota do not own cattle. The real difference between the Ongota and the pastoralists in the area is the absence of cattle rather than the alleged hunter-gathering lifestyle of the Ongota.

\section{NOTES}

1. The Weyt'o River of southwestern Ethiopia (locally called Dullay, Dullayho, etc.) is of course not to be confused with the now extinct Weyto language, spoken by hippopotamus hunters in the Lake Tana. It was probably a Cushitic language (Dimmendaal 1989), later superseded by an occupation jargon based on Amharic.

2. We find it mildly ironic that the very name "Dahalo" is considered derogatory by the group itself; the only native alternative seems to be guћo gwittso "little people" (Tosco 1991): certainly know what you would expect for the original, mighty population of the area.

3. Hajje in Ts'amakko is the plural form of the noun hajo, which indicates a person with magical power.

\section{References}

Azeb Amha. (2001). The Maale language. Leiden: CNWS.

Bendder, Lionel M. (1994). The mistery languages of Ethiopia. In Harold G. Marcus (ed.), New trends in Ethiopian studies. Papers from the 12th International Conference of Ethiopian Studies. Lawrenceville, NJ: Red Sea Press, 1153-1174.

Blažek, Václav. (1991). Comparative analysis of Ongota lexicon. Paper presented at the 21 st Colloquium on African Language and Linguistics, Leiden.

(2005). Cushitic and Omotic strata in Ongota, a moribund language of uncertain affiliation from Southern Ethiopia. Archiv Orientální 73: 43-68. 
(2007). Nilo-Saharan stratum of Ongota. In Mechthild Reh and Doris L. Payne (eds.), Advances in Nilo-Saharan Linguistics: Proceedings of the 8th Nilo-Saharan Linguistics Colloquium, University of Hamburg, August 22-25, 2001. Köln: Köppe, 1-10.

Cupi, Loredana, Sara Petrollino, Graziano Savà, and Mauro Tosco. (2013). Preliminary notes on the Hamar verb. In Marie-Claude Simeone-Senelle and Martine Vanhove (eds.), Proceedings of the 5th International Conference on Cushitic and Omotic Languages. Köln: Köppe, 181-195.

Dimmendaal, Gerrit J. (1989). On language death in Eastern Africa. In Nancy C. Dorian (ed.), Investigating obsolescence: Studies in language contraction and death. Cambridge: Cambridge University Press, 13-31.

Donaldson Smith, Arthur. (1896). Expedition through Somaliland to Lake Rudolf. The Geographical Journal 8: 121-137, 221-239.

Fleming, Harold C., Aklilu Yilma, Ayyalew Mitiku, et al. (1992/93). Ongota or Birale: A moribund language of Gemu-Gofa (Ethiopia). Journal of Afroasiatic Languages 3/3: 181-225.

Fleming, Harold C. (2006). Ongota: A decisive language in Africa prehistory. Wiesbaden: Harrassowitz.

Freeman, Dena, and Alula Pankhurst (eds.). (2001). Living on the edge: Marginalised minorities of craftworkers and hunters in southern Ethiopia. Addis Ababa: Addis Ababa University, Department of Sociology and Social Administration.

Güldemann, Tom, and Rainer Voßen. (2000). Khoisan. In Bernd Heine and Derek Nurse (eds.), African languages: An introduction. Cambridge: Cambridge University Press, 99-122.

Heine, Bernd. (1977). Bemerkungen zur Boni-Sprache (Kenia). Afrika und Übersee 60: 242-295.

Lydall, Jean, and Ivo Strecker. (1979). The Hamar of southern Ethiopia. I: Workjournal. Hohenschaftlarn: Klaus Renner Verlag.

Maddieson, Ian, Siniša Spajić, Bonny Sands, and Peter Ladefoged. (1993). Phonetic structures of Dahalo. Afrikanistische Arbeitspapiere 36: 5-53.

Melesse Getu. (1997). Local versus outsider forms of natural resources use and management: The Tsamako experience in South-West Ethiopia. In Katsuyoshi Fukui, Eisei Kurimoto, and Masayoshi Shigeta (eds.), Ethiopia in broader perspective: Papers of the Thirteenth International Conference of Ethiopian Studies (ICES XIII), Kyoto, 12-17 December 1997. Vol. 2. Kyoto: Shokado, 748-767.

Nurse, Derek. (1986). Reconstruction of Dahalo history through evidence from loanwords. Sprache und Geschichte in Afrika 7(2): 267-305.

Savà, Graziano. (2002). Ts'amakko morphological borrowings in Ongota (or Birale). In Christian Rapold and Graziano Savà (eds.), Proceeding of the 1st International Symposium Ethiopian Morphosyntax in an Areal Perspective. Afrikanistische Arbeitspapiere 71: 75-93.

Savà, Graziano (2005). A grammar of Ts'amakko. Köln: Köppe.

(2010). The Ongota: A branch of Maale? Ethnographic, historic and linguistic traces of contact of the Ongota people. In Echi Gabbert and Sophia Thubauville (eds.), To live with others: Essays on cultural neighbourhood in southern Ethiopia. Köln: Köppe, 213-235. 
Savà, Graziano, and Mauro Tosco (2000). A sketch of Ongota, a dying language of southwest Ethiopia. Studies in African Linguistics 29(2): 59-134.

(2003). The classification of Ongota. In M. Lionel Bender, Gabor Takács, and David Appleyard (eds.), Selected comparative-historical Afrasian linguistic studies in memory of Igor M. Diakonoff. München: Lincom Europa, 307-316.

(2007). Review article of Fleming (2006). Aethiopica 10: 223-232.

Sobania, Neal W. (1980). The historical tradition of the peoples of the Eastern Lake Turkana Basin c. 1840-1925. Unpublished Ph.D. dissertation, University of London, S.O.A.S.

Stiles, Daniel (1988). Historical interrelationships of the Boni with pastoral peoples of Somalia and Kenya. Kenya Past and Present 20: 38-45.

Tosco, Mauro (1991). A grammatical sketch of Dahalo, including texts and a glossary. Hamburg: Buske.

(1992). Dahalo: An endangered language. In Matthias Brenzinger (ed.), Language death: Factual and theoretical explorations. Berlin: Mouton de Gruyter, 137-155.

(1994). The historical reconstruction of a southern Somali dialect: Proto-Karre-Boni. Sprache und Geschichte in Afrika 15: 153-209.

(1998). "People who are not the language they speak:" On language shift without language decay in East Africa. In Matthias Brenzinger (ed.), Endangered languages in Africa. Köln: Köppe, 119-142.

(2007). Something went wrong: On the historical reconstruction of the Dhaasanac verb. In Rainer Voigt (ed.), From beyond the Mediterranean. Akten des 7. internationalen Semitohamitistenkongresses (VII. ISHaK), Berlin 13. bis 15. September 2004. Aachen: Shaker, 265-280. 